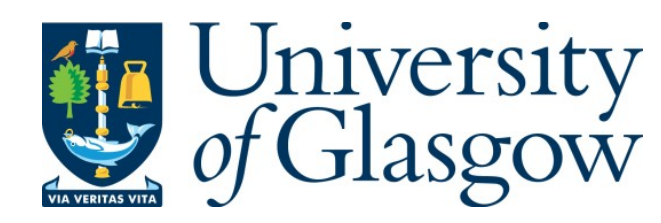

Draycott, J. (2015) Reconstructing the lived experience of disability in antiquity: a case study from Roman Egypt. Greece and Rome, 62(2), pp. 189-205.

There may be differences between this version and the published version. You are advised to consult the publisher's version if you wish to cite from it.

http://eprints.gla.ac.uk/130293/

Deposited on: 10 November 2016

Enlighten - Research publications by members of the University of Glasgow http://eprints.gla.ac.uk 


\section{Reconstructing the Lived Experience of Disability in Antiquity: A Case Study from Roman Egypt ${ }^{1}$}

\section{Introduction}

Over the last thirty years, the development of disability studies as an academic discipline has in turn ensured that interest in disability in historical periods has steadily increased. ${ }^{2}$ Initially, scholars presented an overwhelmingly negative view of disability in antiquity, proceeding under the assumption that babies born displaying visible signs of deformity or disability were subjected either to infanticide or exposure, and that individuals who were subsequently identified as suffering from a deformity or disability, or developed either one later in life, were ostracized and unable to make any meaningful contribution to society. ${ }^{3}$ It is only over the last decade that this reductive approach has been gradually discredited, and the understanding of disability in antiquity has become increasingly nuanced. To date, one monograph has been published on deformity and disability in the Graeco-Roman world, one monograph has been published on disability in the Greek

\footnotetext{
* I would like to thank Dr Liz Gloyn and Greece \& Rome's anonymous reviewer for their feedback on earlier drafts of this article. Some of the material included here was presented at the Universities in Wales Institute of Classics and Ancient History's annual colloquium at Gregynog Hall in 2014, and at Royal Holloway, University of London's Department of Classics research seminar in 2015, and I would like to thank those who attended these events for their questions and comments, and the fruitful discussions that grew out of them.

${ }^{1}$ All abbreviations of ancient literature follow the Oxford Classical Dictionary (third edition), and all abbreviations of documentary papyri follow Duke University's Checklist of Editions of Greek, Latin, Demotic, and Coptic Papyri, Ostraca, and Tablets

$<$ http://library.duke.edu/rubenstein/scriptorium/papyrus/texts/clist.html > accessed April 2015. The definition of disability utilized throughout this paper is that of the World Health Organisation: 'An umbrella term, covering impairments, activity limitations, and participation restrictions. An impairment is a problem in body function or structure; an activity limitation is a difficulty encountered by an individual in executing a task or action; while a participation restriction is a problem experienced by an individual in involvement in life situations'. See < http://www.who.int/topics/disabilities/en/ > accessed April 2015. ${ }^{2}$ C. Kudlick, 'Disability History: Why We Need an "Other"', Amer. Hist. Rev. 108.3 (2003), 763-93. ${ }^{3}$ W. Southwell-Wright, 'Past Perspectives: What can Archaeology offer Disability Studies?', in M. Wappett and K. Arndt (eds.) Emerging Perspectives on Disability Studies (New York, 2013), 67-97; on disabled children in antiquity, see C. Laes, 'Raising a Disabled Child', in J. Grubbs, T. Parkin, and R. Bell (eds.) The Oxford Handbook of Childhood and Education in the Classical World (Oxford, 2013), 125-44.
} 
world and one on disability in the Roman world, and one edited volume has been

published on disability in antiquity and another on disability in the Roman world. ${ }^{4}$ These

have been complemented by investigations into disability in Judaism, Christianity and the

Bible. ${ }^{5}$ There are, however, issues with the approaches taken in these studies, primarily

their reliance on works of ancient literature written by predominantly elite males who

were not themselves deformed or disabled. ${ }^{6}$ The validity of attempting the retrospective

diagnosis of health problems suffered by historical individuals is also questionable. ${ }^{7}$

Considering the move towards the use of history, archaeology, and anthropology to show

disabled people that their experiences are not uniquely contemporary, with disabled

activists utilizing the disciplines to construct historical identities for themselves and their

peers, I believe that it is worthwhile to consider the lived experience of ordinary disabled

\footnotetext{
${ }^{4}$ R. Garland, The Eye of the Beholder. Deformity and Disability in the Graeco-Roman World (London, 1995 and 2010); M. L. Rose, The Staff of Oedipus. Transforming Disability in Ancient Greece (Ann Arbor MI, 2003 and 2013); C. Laes, Bepurkt? Gehandicapten in het Romeinse rijk (Leuven, 2014); R.

Breitwieser, Behinderungen und Beeinträchtigungen/Disability and Impairment in Antiquity (Oxford, 2012); C. Laes, C. F. Goodey, and M. L. Rose, Disabilities in Roman Antiquity. Disparate Bodies a Capite ad Calcem (Leiden, 2013). Articles surveying the period include N. Kelley, 'Deformity and Disability in Greece and Rome', in H. Avalos, S. Melcher, and J. Schipper (eds.) This Abled Body. Rethinking Disabilities in Biblical Studies (Atlanta GA, 2007), 31-45. The remit and the terminology utilized with regard to impairment, disability, deformity, disfigurement etc. varies according to author. Also useful is the Disability History and the Ancient World research network, which includes a comprehensive and regularly updated subject bibliography, available at < http://www.disability-ancientworld.com/index.htm $>$ accessed April 2015.

${ }^{5}$ A. Ohry and E. Dolev, 'Disabilities and Handicapped People in the Bible', Koroth 8.5-6 (1982), 63-7; J. Abrams, Judaism and Disability. Portrayals in Ancient Texts from the Tanach through the Bavli (Washington DC, 1998); H. Avalos, S. Melcher, and J. Schipper (eds.) This Abled Body. Rethinking Disabilities in Biblical Studies (Atlanta GA, 2007); S. Fishbane (ed.), Deviancy in Early Rabbinic Literature. A Collection of Socio-Anthropological Essays (Leiden, 2008); S. Olyan, Disability in the Hebrew Bible. Interpreting Mental and Physical Differences (Cambridge, 2008); N. Kelley, 'The Deformed Child in Ancient Christianity', in C. Horn and R. Phenix (eds.) Children in Late Ancient Christianity (Tübingen, 2009), 199-216.

${ }^{6}$ Such approaches have recently been critiqued by Southwell-Wright (n. 3), 78-9.

7 The use of retrospective diagnosis to elucidate health in antiquity has been subject to a significant amount of criticism over the last decade. See K.-H. Leven, "At Times These Ancient Facts Seem to Lie Before Me Like a Patient on a Hospital Bed" - Retrospective Diagnosis and Ancient Medical History', in H. F. J. Horstmanshoff and M. Stol (eds.), Magic and Rationality in Ancient Near Eastern and Graeco-Roman Medicine (Leiden, 2004), 369-86; and also L. A. Graumann, 'Monstrous Births and Retrospective Diagnosis: the Case of Hermaphrodites in Antiquity’, in Laes, Goodey, and Rose (n. 4), 181-209.
} 
people in antiquity, as opposed to the extraordinary ones - such as, for example, the emperor Claudius - who are most often the subject of scholarly enquiry. ${ }^{8}$

\section{Disability in Antiquity}

Approaching disability in antiquity is problematic for a number of reasons, chief of which is the lack of firsthand accounts of what it was like to actually be 'disabled': in point of fact, in antiquity there was no such official category of person, and thus no such official individual or collective identity as there is today. ${ }^{9}$ Additionally, in order to understand the 'abnormal' body, it is also necessary to establish what, precisely, constituted a 'normal' body. ${ }^{10}$ While works of ancient literature from a variety of genres refer to a variety of disabled individuals and the ways in which they learned to manage their conditions, these brief accounts were not only written down a long time after the individual had actually

\footnotetext{
${ }^{8}$ M. Cross, 'Accessing the Inaccessible: Disability and Archaeology', in T. Insoll (ed.) The Archaeology of Identities. A Reader (Abingdon, 2007), 179, 186; J. Hubert, 'Introduction: The Complexity of Boundedness and Exclusion', in J. Hubert (ed.) Madness, Disability and Social Exclusion. The Archaeology and Anthropology of 'Difference' (Abingdon, 2000), 2. For discussion of how best to approach the disabled body in history and culture, and the importance of incorporating the perspectives of disabled scholars, see D. Mitchell and S. Snyder, 'Introduction: Disability Studies and the Double Bind of Representation', in D. Mitchell and S. Snyder (eds.) The Body and Physical Difference. Discourses of Disability (Ann Arbor MI, 1997), 2. For a recent example of this approach to disability history, see the Wellcome Trust funded project 'All the King's Fools' < http://www.allthekingsfools.co.uk/site/ > accessed April 2015. For an interim report on this project, see S. Lipscombe, 'All the King's Fools', History Today 61.8 (2011), available at < http://www.historytoday.com/suzannah-lipscomb/all-kings-fools > accessed April 2015. For the importance of considering the ordinary individual, and the use of bioarchaeological evidence in the form of a collection of disparate burials from the Via Collatina in Rome in order to do so, see E.-J. Graham, 'Disparate Lives or Disparate Deaths? Post-mortem Treatment of the Body and the Articulation of Difference', in Laes, Goodey, and Rose (n. 4), 249-74.

${ }^{9}$ The closest we can get is $\alpha \delta \delta$ vo $\alpha$ - literally 'unable' - in Lys. 24; V. Wohl, 'Rhetoric of the Athenian Citizen', in E. Gunderson (ed.) The Cambridge Companion to Ancient Rhetoric (Cambridge, 2009), 162-77 translates it as 'disabled', while Rose (n. 4), 95-8 disputes this translation and the resulting interpretation of the speech. See Rose (n. 4), 11-14 on the range of terms used in ancient Greek to refer to physical imperfection and impairment. Garland (n. 4), 4-7 discusses the terms used in ancient Greek and Latin to refer to physical abnormality. On the possibility that deformities and disabilities inspired 'monstrous races' in ancient mythology, see B. Gevaert and C. Laes, 'What's in a Monster? Pliny the Elder, Teratology and Bodily Disability', in Laes, Goodey, and Rose (n. 4), 223-4; on segregated communities consisting of individuals with disabilities, 226-7. A couple of examples of the latter are attested in ancient literature: Gregory of Tours, Vita Andreae 32 (a blind community); August. De quantitate animae 18, 31 (a deaf-mute community).

${ }^{10}$ On the 'normal' Roman body, Graham (n. 8), 254-8.
} 
lived, but were also subject to a degree of mythologization. A case in point is that of

Marcus Sergius Silus, who lost his right hand in a military campaign during the Second

Punic War (218-01 BC), replaced it with an iron one that he used to hold his shield, and

continued to fight using his left hand to wield his sword instead:

No person living, in my opinion at least, ever excelled M. Sergius, although his great-grandson, Catiline, tarnished the honours of his name. In his second campaign he lost his right hand; and in two campaigns he was wounded three and twenty times; so much so, that he could scarcely use either his hands or his feet; still, attended by a single slave, he afterwards served in many campaigns, though but an invalided soldier. He was twice taken prisoner by Hannibal (for it was with no ordinary enemy that he would engage), and twice did he escape from his captivity, after having been kept, without a single day's intermission, in chains and fetters for twenty months. On four occasions he fought with his left hand alone, two horses being slain under him. He had a right hand made of iron, and attached to the stump, after which he fought a battle, and raised the siege of Cremona, defended Placentia, and took twelve of the enemy's camps in Gaul. All this we learn from an oration of his, which he delivered when, in his praetorship, his colleagues attempted to exclude him from the sacred rites, on the ground of his infirmities. What heaps upon heaps of crowns would he have piled up, if he had only had other enemies! ... Other persons have been conquerors of men, no doubt, but Sergius conquered even Fortune herself. ${ }^{11}$

In turn, while epistolography can certainly help us reconstruct the health problems experienced by members of the Roman senatorial elite like Cicero, Seneca the Younger, and Pliny the Younger, by members of their families, and by their friends and acquaintances, none of these individuals were themselves disabled. The difference in

\footnotetext{
${ }^{11}$ Plin. HN 7.28.104-5. On prosthetic limbs in antiquity, see L. Bliquez, 'Prosthetics in Classical Antiquity: Greek, Etruscan, and Roman Prosthetics', in ANRW 37.3 (1996), 2662-74, but all surviving Roman examples are either legs or feet, as opposed to arms or hands. On using a wound to one's advantage in popular rhetoric, see M. Leigh, 'Wounding and Popular Rhetoric at Rome', BICS 40.1 (1995), 195-215. On war wounds in antiquity as a sign of heroism and valour, see C. Salazar, The Treatment of War Wounds in Graeco-Roman Antiquity (Leiden, 2000); with particular reference to the war wounds of kings, see E. Samama, 'A King Walking with Pain? On the Textual and Iconographical Images of Phillip II and Other Wounded Kings', in Laes, Goodey, and Rose (n. 4), 231-48. On the extent to which this account of Marcus Sergius Silus is subject to Pliny's own personal moral and philosophical outlook, see M. Beagon, 'Beyond Comparison: M. Sergius Silus, Fortunae Victor', in G. Clark and T. Rajak (eds.) Philosophy and Power in the Graeco-Roman World. Essays in Honour of Miriam Griffin (Oxford, 2002), 111-32.
} 
attitude toward those who were, in fact, permanently disabled is notable. Pliny the

Younger's description of the senator Gnaeus Domitius Tullus is a case in point:

In [his will] Tullus acknowledges his obligations to all his relatives in return for their services to him, as he does to the excellent wife who had borne with him so long ... It was thought most unsuitable that a woman of her high birth and blameless character, who was no longer young, had borne children in the past and had long been widowed, should marry a wealthy old man and a hopeless invalid, whom even a wife who had known him when young and healthy might have found an object of disgust. Crippled and deformed in every limb, he could only enjoy his vast wealth by contemplating it and could not even turn in bed without assistance. He also had to have his teeth cleaned and brushed for him - a squalid and pitiful detail - and when complaining about the humiliations of his infirmity was often heard to say that every day he licked the fingers of his slaves. Yet he went on living, and kept his will to live, helped chiefly by his wife, whose devoted care turned the former criticism of her marriage into a tribute of admiration. ${ }^{12}$

Whereas Sergius Silus serves as role model who is proud of a disability which he believes serves as a permanent indicator of his valour, and who defends himself against detractors who seek to marginalize him because of it, Domitius Tullus is presented as a pathetic creature who is not only fully aware of the indignity of his situation, but also vocalizes this awareness. Yet both Sergius Silus and Domitius Tullus are presented to us by writers with agendas of their own, rather than by the individuals themselves, on their own terms, and in their own words. ${ }^{13}$

However, a compromise can, perhaps, be reached if the documentary papyri from Graeco-Roman Egypt are considered as a potential source of information not just about the range of disabilities suffered by individuals, but also about the extent to which these

\footnotetext{
${ }^{12}$ Plin. Ep. 8.18.

${ }^{13}$ See C. Laes, 'How Does One Do a History of Disability in Antiquity? One Thousand Years of Case Studies', Medicina nei Secoli Arte e Scienza 23.3 (2011), 915-46 for the possibility of exploring disability in antiquity through case studies which can be contextualized and, consequently, read on different levels, and C. Laes, 'Unabling Zercon oder Disabled Zercon? Ein Nar an Attilas Hof', Werkstatt Geschichte 65 (2013), 29-39 for an additional individual case study.
} 
disabilities impacted upon their quality of life. ${ }^{14}$ Thus for the remainder of this paper, I will focus on one particular individual, Gaius Gemellus Horigenes from Karanis in the Fayum, to determine the extent to which a disability (a visual impairment in the form of the loss of one eye and, subsequently, the development of a cataract in the other) affected his life. Thanks to the discovery of his family's archive in a subterranean storage chamber in House 5006 in Karanis during archaeological excavations by the University of Michigan in 1924, we have a considerable amount of information not just about him, but also about his family, and his local community, which means that Gaius Gemellus Horigenes is one of the ancient world's most well-documented and contextualised disabled individuals. ${ }^{15}$

\section{Gaius Gemellus Horigenes}

Gaius Gemellus Horigenes, also known as Gemellus Horion, and Horion, was born in around AD 171 to Gaius Apollinarius Niger and Tasoucharion. ${ }^{16}$ His grandfather, Gaius Julius Niger, was an Antinoopolite of the Osirantis tribe and a discharged cavalryman of the ala veterana Gallica, a status which brought Roman citizenship with it. The

\footnotetext{
${ }^{14}$ Papyrological evidence has only recently begun to be systematically incorporated into discussions of disability in antiquity, see Laes (n. 4). On disabled individuals and disability in papyri, see P. Arzt-Grabner, 'Behinderungen und Behinderte in den griechischen Papyri', in Breitwieser (n. 4), 47-55; G. Cernuschi, Nuovi contributi per lo studio dei connotati personali nei documenti dell 'egitto greco-romano (Padua, 2010); G. Nachtergael, 'Papyrologica. II.', Chron. d'É 80, Fasc. 159-60 (2005), 244-5; S. Strassi, 'Nomi parlanti nell' Egitto greco e romano', Akten des 21. Internationalen Papyrologenkongresses (Berlin, 1995 and 1997), 922-30. A number of papyri refer to individuals using their disabilities as distinguishing features, presumably as a means of ensuring/confirming identification, see for example P.Mich. V 293 (early first century AD, Tebtunis), which refers to 'Apynchis the so-called deaf-mute', P.Mich. V 325 (AD 47, Tebtunis), which refers to 'the lame Heraklous', P.Mich. inv. 4172 (AD 173-4, Karanis), which refers to 'Maximus the leper', P.Mich. XII 651 (AD 360, Karanis), which refers to 'Nilos, dumb'.

${ }^{15}$ For discussion of the documentary papyri from the archive, see I. Biezunska-Malowist, 'La famille du vétéran romain C. Iulius Niger de Karanis', Eos 49 (1957), 155-64 and R. Alston, Soldier and Society in Roman Egypt. A Social History (London, 1995), 129-32. See also the entry at Papyrus Archives in GraecoRoman Egypt $<$ www.trismegistos.org/archive/90 $>$ accessed April 2015.

${ }^{16}$ P.Mich. VI $423-4$.
} 
Antinoopolite and Roman citizenships would probably have passed to his sons, but while Gaius Gemellus Horigenes was certainly an Antinoopolite, he was not necessarily a Roman citizen (his mother, Tasoucharion, was not one); he does not claim to be one in writing until AD 214. ${ }^{17}$ Gaius Julius Niger settled in the village of Karanis, and over time he and his family amassed a sizeable portfolio of at least four houses and seven courtyards, as well as interests in other houses and courtyards, olive yards, garden lands, and grain lands in the villages of Karanis, Psenarpsenesis, Kerkesoucha, and Bakchias. Both Gaius Julius Niger and Gaius Apollinarius Niger were dead by AD 187, survived by Gaius Gemellus Horigenes, his sister Gaia Apollinaria, and their mother Tasoucharion. ${ }^{18}$

We can begin to establish a context for Gaius Gemellus Horigenes and his family using the data contained in the more than three hundred census returns that survive from Roman Egypt, spanning the period AD 11-12 to AD 257-8. These documents have been comprehensively examined in an attempt to establish the size and structure of Egyptian households, age and sex distribution, and patterns of mortality, marriage, fertility, and migration, and it has been suggested that life expectancy at birth in this period would have been in the early to mid twenties, with male life expectancy slightly more favourable than female; male life expectancy at birth would have been at least twentyfive years, while female life expectancy at birth would probably have been twenty-two and a half years, increasing at age ten to between thirty-four and a half and thirty-seven and a half years. ${ }^{19}$ Thus when we first meet Gaius Gemellus Horigenes as a twenty-six

\footnotetext{
${ }^{17}$ SB XII 11114, a legal petition. Alston (n. 15), 130-1 believes that Gaius Gemellus Horigenes was attempting to claim Roman citizenship through his grandfather, rather than through the Constitutio Antoniniana of AD 212, as a means of inflating his status.

${ }^{18}$ P.Mich. VI 370, a census declaration dated to AD 189.

${ }^{19}$ R. S. Bagnall and B. W. Frier, The Demography of Roman Egypt (Cambridge, 1994 and 2006), 1; female life expectancy at 90; male life expectancy at 100. Unfortunately, analysis of this evidence does not provide anything like a complete picture of the population of Roman Egypt as the vast majority of the census
} 
year old man in AD 197, he is to all intents and purposes middle-aged. Considering his social status, property, and wealth, we might reasonably expect him have married and started a family at some point between then and when he is last attested in the family archive in AD 214, when he would have been around forty-three years old, but there is no indication that he ever did. ${ }^{20}$ Might his disability have had something to do with his highly unusual unmarried status?

Over a period of several years, Gaius Gemellus Horigenes submitted a number of legal petitions to various members of the Roman imperial administration of the province of Egypt, and it is the contents of these petitions, when used in conjunction with information gleaned from other documents in his family archive, that is particularly informative about his disability and the impact that it had upon his quality of life. ${ }^{21}$ Gaius Gemellus Horigenes did not write these petitions himself due to the fact that he was illiterate, which may or may not have been one result of his disability, as his family's archive contains literary papyri which suggest that one or more members of it were not

returns come from three nomes out of fifty (the Arsinoite, the Oxyrhynchite and the Prosopite) and date from the second century AD, but the limitations of the material are made perfectly clear and are taken into account throughout the analysis. See also S. Huebner, The Family in Roman Egypt. A Comparative Approach to Intergenerational Solidarity and Conflict (Cambridge, 2013), 21-8 on the strengths and weaknesses of this material with regard to investigating the Romano-Egyptian family.

${ }^{20}$ According to the calculations of Bagnall and Frier (n. 19), 146, the average age of paternity was thirtynine years old. On the question of the age of marriage of males in Graeco-Roman Egypt, see A. Pudsey, 'Nuptiality and the Demographic Life Cycle of the Family in Roman Egypt', in C. Holleran and A. Pudsey (eds.), Demography and the Graeco-Roman World. New Insights and Approaches (Cambridge, 2011), 6098. According to Pudsey, marriage was 'near universal', with men usually marrying in their early twenties, half of men marrying by the age of twenty-five, and seventy per cent of men marrying by their mid-forties. Men were also much more likely than women to remarry after the death of a spouse. See also Huebner (n. 19) 48 on marriage patterns in Roman Egypt, and 94-7 on remarriage after the death of a spouse.

${ }^{21}$ These petitions have been the subject of scholarly attention on several previous occasions, albeit for different reasons each time. See Alston (n. 15), 129-32 for discussion of the Roman army veteran community in the village of Karanis in Egypt, D. Frankfurter, 'Fetus Magic and Sorcery Fears in Roman Egypt', GRBS 46 (2006), 37-62, and A. Z. Bryen and A. Wypustek, 'Gemellus' Evil Eyes (P.Mich. VI 423-424)', GRBS 49 (2009), 535-55 for discussion of the use of magic, and J. L. Draycott, Approaches to Healing in Roman Egypt (Oxford, 2012), 64-6 for discussion of eye conditions in Egypt. 
only functionally literate, but also highly educated. ${ }^{22}$ However, he presumably dictated his petitions to the individuals who did write them, and approved the final version of each before witnessing, signing, and submitting them, so we can trust that the content is an accurate representation of the complaints he wished to make, whether or not those complaints represented the events that had actually occurred. ${ }^{23}$

The first petition, addressed to the prefect of Egypt Quintus Aemilius Saturninus, is dated to between February and May AD 197. ${ }^{24}$ Gaius Gemellus Horigenes opens the petition by stating that he and his sister initially inherited the property and possessions of their father and uncle without any objections - clearly neither his father nor his uncle appear to have considered his disability sufficient reason for disinheriting him - but that recently they have encountered some opposition to their activities from two individuals who are presumably their neighbours, and evidently individuals of some influence:

Julius and Sotas, both sons of Eudas, wrongfully, with violence and arrogance, entered my fields after I had sown them and hindered me therein through the power which they exercise in the locality, contemptuous of me on account of my weak vision. ${ }^{25}$

\footnotetext{
${ }^{22}$ The first petition, P.Mich. VI 422, was written by an individual named Sabinus; the second petition, P.Mich.VI 423, does not name the scribe; the third petition, P.Mich. VI 425, was written by individuals named Germanus and [ ...] son of Panebtichis; and the fourth petition, P.Mich. VI 426, does not name the scribe. See W. V. Harris, Ancient Literacy (Cambridge MA, 1989), particularly 5-7 for the difficulty in differentiating between 'literate', 'semi-literate' and 'illiterate', and 'cultured' and 'uncultured' in GraecoRoman antiquity. On education and literacy in Roman Egypt, see R. Cribiore, Gymnastics of the Mind. Greek Education in Hellenistic and Roman Egypt (Princeton NJ, 2001). On the literary papyri included amongst the documents of the family's archive, see P. van Minnen, 'Boorish or Bookish? Literature in Egyptian Villages in the Fayum in the Graeco-Roman Period', JJP 28 (1998), 111, 132. Gaius Julius Niger was in the habit of signing his own petitions, see $S B$ XXIV 16252.33-4.

${ }^{23}$ See A. Bryen, Violence in Roman Egypt. A Study in Legal Interpretation (Philadelphia PA, 2013), 4-5 for discussion of the extent to which petitioners exaggerated their circumstances in order to maximize their petitions' possibilities of success when seeking recompense for interpersonal violence.

${ }^{24}$ P.Mich. VI 422. For the full Greek text and English translation, see < www.papyri.info $>$ accessed April 2015.

${ }^{25}$ P.Mich. VI 422.20-30. In a subsequent document, P.Mich. VI 398, a tax receipt dated to AD 207, Julius is included as a tenant farmer of Gaius Gemellus Horigenes, but whether he was a tenant farmer at this point in time is unfortunately unknown.
} 
So according to Gaius Gemellus Horigenes, the reason that Julius and Sotas hampered his efforts to harvest his crops was that they despised him (the verb used is $\kappa \alpha \tau \alpha \phi \emptyset o v \varepsilon ́ \omega$ ) specifically because of the weakness or potentially disease/sickness ( $\dot{\alpha} \sigma \theta \varepsilon \dot{v} \varepsilon\llcorner\alpha)$ of his vision (ö $\psi \iota \varsigma)$. Since the brothers seem to have been influential in the local community, their negative treatment of Gaius Gemellus Horigenes might well have been adopted by others, either in imitation of them, or in solidarity.

The second petition, addressed to the strategos (local governor) of the Herakleides division of the Arsinoite nome Hierax Nemesion, is dated 22 May AD $197 .^{26}$ It not only provides more details concerning the events described in the first petition, but also describes an incident that occurred after that petition had been submitted, indicating that hostilities between Gaius Gemellus Horigenes, Julius and Sotas had escalated to such a degree that even the recent death of Sotas had not defused the situation:

Julius, also acting with the violence characteristic of them, entered the fields that I had sown and carried away a substantial quantity of hay; not only that, but he also cut dried olive shoots and heath plants from my olive grove near the village of Kerkesoucha. When I came there at the time of the harvest, I learned that he had committed these transgressions. In addition, not content, he again trespassed with his wife and a certain Zenas, having with them a brephos, intending to hem in my cultivator with malice so that he should abandon his labour after having harvested in part from another allotment of mine, and they themselves gathered in the crops. When this happened, I went to Julius in the company of officials, in order that these matters might be witnessed. Again, in the same manner, they threw the same brephos toward me, intending to hem me in also with malice, in the presence of Petesouchos and Ptollas, elders of the village of Karanis who are exercising also the functions of the village secretary, and of Sokras the assistant, and while the officials were there, Julius, after he had gathered in the remaining crops from the fields, took the brephos away to his house. ${ }^{27}$

\footnotetext{
${ }^{26}$ P.Mich. VI 423-4. For the full Greek text and English translation, see $<\underline{w w w . p a p y r i . i n f o}>$ accessed April 2015.

${ }^{27}$ P.Mich. VI 423-4.7-23.
} 
Gaius Gemellus Horigenes repeats his belief that he was targeted specifically because of

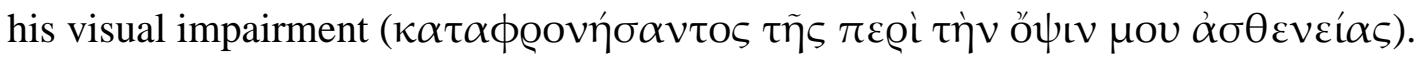

However, whereas on the previous occasion Julius and Sotas simply trespassed on Gaius Gemellus Horigenes' property and hampered his efforts to harvest his crops, on this occasion Julius not only enlisted others, but also went so far as to use magic against him, utilising a brephos (a foetus) as a means of casting a binding spell first upon Gaius Gemellus Horigenes' employee to prevent him harvesting his employers crops and then objecting to the brothers' theft of them, and then upon Gaius Gemellus Horigenes himself and the officials he enlisted to help him resolve the situation. ${ }^{28}$ There is an additional complication: due to Julius stealing Gaius Gemellus Horigenes' crops, he is unable to pay his taxes. ${ }^{29}$

The third petition, addressed to the epistrategos (regional governor) Calpurnius Concessus, is dated to 26 August AD 198, and is concerned with a different individual to the first two: a tax collector's assistant by the name of Kastor:

This person, who held me in contempt because of my infirmity - for I have only one eye and I do not see with it although it appears to have sight, so that I am utterly worthless in both - victimized me, having first publicly abused me and my mother, after maltreating her with numerous blows and demolishing all four doors of mine with an axe so that our entire house is wide open and accessible to every malefactor. These were demolished and we were beaten although we owed nothing to the fiscus, and for this reason he dared not even produce a receipt lest he be convicted through it of injustice or of extortion. ${ }^{30}$

\footnotetext{
${ }^{28}$ For discussion of this incident, the only surviving firsthand example of an appeal to Roman imperial administrators to resolve a situation involving magic, see Frankfurter (n. 21). For further discussion of this incident, and the suggestion that the form of magic utilized, with its connotations of the Evil Eye, was related to Gaius Gemellus Horigenes' visual impairment, see Bryen and Wypustek (n. 21), 549-52. On the Evil Eye, see Plut. Mor. 680C-83B; Heliod. Aeth. 3.7-9; both discussed in M. Dickie, 'Plutarch and Heliodorus on the Evil Eye', C Phil. 86.1 (1991), 17-29.

${ }^{29}$ P.Mich. VI 423-4.23-6.

${ }^{30}$ P.Mich. VI 425. For the full Greek text and English translation, see $<\underline{w w w . p a p y r i . i n f o}>$ accessed April 2015.
} 
Since the collection of taxes in Egypt was contracted out to the highest bidder, and those who bid for the privilege did so with the aim of making as much profit as possible, it was not unusual for members of the imperial administration to receive complaints about tax gatherers, or members of their staff such as assistants or armed guards.$^{31}$ However, since Gaius Gemellus Horigenes and his family have paid their taxes, Kastor's behaviour cannot be explained as having occurred in an official capacity. Rather, the explanation that Gaius Gemellus Horigenes gives for being harassed by Kastor is similar to the one he

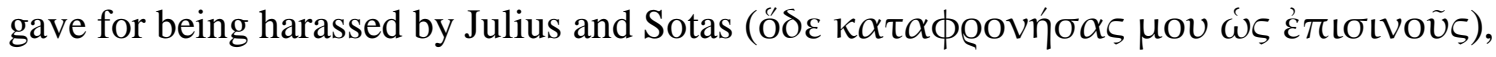
although on this occasion he gives specific details regarding his condition: he only has

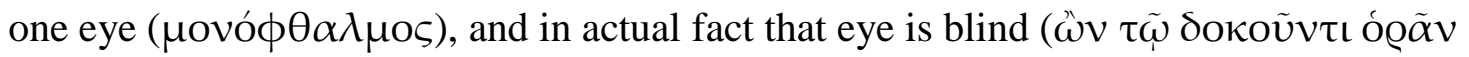

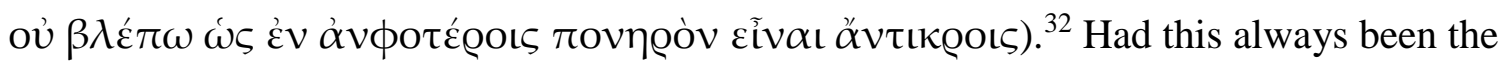
case, or had his circumstances changed, with a sudden deterioration in the sight in his remaining eye taking his vision from weak in AD 197 to virtually non-existent in AD 198? However, it is apparent that Kastor has not confined his attentions to Gaius Gemellus Horigenes, but has also assaulted his mother and vandalized the family home, which implies that it is the entire family, and their property, rather than just Gaius Gemellus Horigenes himself, which is made vulnerable by his disability.

The fourth petition, addressed to the epistrategos (regional governor) Arrius Victor, is dated to AD 199-200, and is concerned with legal and financial matters, rather than criminal activity as Gaius Gemellus Horigenes has been signed up to a liturgy (a

\footnotetext{
${ }^{31}$ N. Lewis, Life in Egypt under Roman Rule (Oxford, 1983), 161. There are numerous ancient literary references that present tax collectors in a very negative light, see for example Matthew 9.10; Mark 2.16; Luke 3.12-14, 5.30, 7.34; Philo, Leg. 3.30; and documentary papyri attest the same, see for example P.Sakaon 41/P.Ryl. IV 659 (AD 323/4).

${ }^{32}$ P.Mich. VI 425.12-14.
} 
type of public service) that he is apparently exempt from, and thus wishes to be relieved of the liability for. ${ }^{33}$ It contains the most detailed description of Gaius Gemellus Horigenes' visual impairment of all the documents in the archive: he only has one eye,

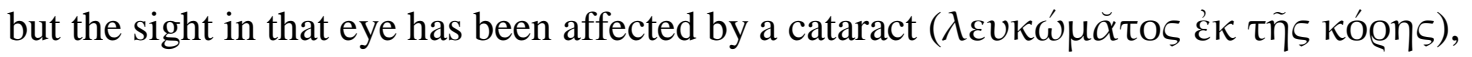
so to all intents and purposes, he is completely blind. It is unfortunate that the petition is damaged just at the point where Gaius Gemellus Horigenes begins describing the 'habitual violence and arrogance' of the Karanis elders towards him, as this would have been crucial information for understanding the elders' motivations in appointing Gaius Gemellus Horigenes to a liturgy which he was not required to perform. If a man was appointed to a liturgy in error, the official or officials that nominated him were responsible for organising a substitute, and if one could not be found, they were liable for the liturgy themselves. ${ }^{34}$ If they were found to have acted deliberately and maliciously, they could be fined and ordered to pay compensation. ${ }^{35}$ Was there, therefore, some sort of consensus regarding Gaius Gemellus Horigenes and his place in the local community, not only amongst the elders of Karanis, but also the other inhabitants of the village?

Based on the details contained in the petitions, it is safe to say that Gaius Gemellus Horigenes is an appropriate subject for a case study for the lived experience of disability in antiquity. So what impact did his disability have on his quality of life? While blindness (whether congenital or acquired) was certainly a serious condition in antiquity, it was not unusual. ${ }^{36}$ Eye disease was common, and though congenital blindness was in

\footnotetext{
${ }^{33}$ P.Mich. VI 426.

${ }^{34}$ Lewis (n. 31), 180-1. See for example, P.Phil. 1/P.Oxy. VIII 1119 (AD 244, Oxyrhynchus).

${ }^{35}$ See for example P.Wisc. II 81 (AD 143, Karanis).

${ }^{36}$ On visual impairments in the Roman world, see L. Trentin, 'Exploring Visual Impairment in Ancient Rome', in Laes, Goodey, and Rose (n. 4). On eye medicine in the Roman world, see R. Jackson, 'Eye Medicine in the Roman Empire.” ANRW 37.3 (1996), 2228-51. On ophthalmology in Roman Egypt, see
} 
all likelihood very rare, acquired blindness could occur through a range of means:

accident, injury, assault, or even just the aging process. ${ }^{37}$ As a member of the provincial elite, in possession of money, property, land, staff, and supportive family members in the form of his mother and sister, Gaius Gemellus Horigenes was not necessarily automatically heavily impacted in a negative way by his disability, certainly not to the extent that somebody without his resources would have been. ${ }^{38}$ However, according to Gaius Gemellus Horigenes himself, the reason that he was harassed, had his crops stolen, had magical spells cast upon him, was (along with his mother) verbally abused and physically assaulted, and had his home vandalized was because other members of the community despised him because of his disability.

Why did Gaius Gemellus Horigenes feel that it was necessary to include this information in each one of the petitions? Richard Alston believes that 'his emphasis on his status and disability were tactics to ensure that officials would take up his case' ${ }^{39}$ This assumes that the prefect of Egypt, the strategos, and the epistrategos would be inclined to be sympathetic, not only because a high status individual was experiencing harassment, but also because a disabled individual was experiencing harassment. ${ }^{40}$ It was not unusual for members of disadvantaged groups such as widows, orphans, the childless, the elderly, foreigners, or member of minority religious sects to draw attention to their

M.-H. Marganne, L' ophtalmologie dans l'Egypte gréco-romaine d'après les papyrus littéraires grecs (Leiden, 1994).

${ }^{37}$ Trentin (n. 36), 95-106.

${ }^{38}$ For acknowledgement of the role that status, class, and wealth could play in altering someone's experience of disability, see C. Laes, C. F. Goodey, and M. L. Rose, 'Approaching Disabilities a Capite ad Calcem: Hidden Themes in Roman Antiquity', in Laes, Goodey, and Rose (n. 4), 8. See also Trentin (n. 36), 108-11 with specific reference to visual impairment.

${ }^{39}$ Alston (n. 15), 131.

${ }^{40}$ However, Gaius Gemellus Horigenes includes information about his visual impairment in official documents that are not petitions. See for example $S B$ IV 7360, a declaration of land holdings dated to 4 March AD 214, in which he denotes himself as having weak vision ( $\tau \tilde{\eta}$ ö $\psi \varepsilon \iota \dot{\alpha} \sigma \theta \varepsilon v \eta ́ \varsigma)$. 
straitened circumstances when petitioning for assistance in an attempt to garner

sympathy. Certainly, an additional notation on the third petition indicates that the epistrategos Calpurnius Concessus was inclined to take the matter seriously: 'Petition his excellency the epistrategos, who will not be found wanting in matters within his jurisdiction. Return to the petitioner'. ${ }^{41}$ That the imperial or provincial administration might take exception to the poor treatment of a disabled individual, poor treatment that seems to have occurred as a direct result of his disability, runs counter to just about everything we know (or think we know) about the place of the disabled in antiquity.

\section{Attitudes towards Disability in Antiquity}

While the works of Martha Rose (previously Martha Edwards) and Christian Laes in particular have argued for a more nuanced view of the experience of being disabled in antiquity, and Emma-Jayne Graham has recently drawn attention to what she designates a 'sliding scale of physical impairment', it is undeniable that in ancient Greek and Roman culture, deformed and disabled individuals were treated not only differently from ablebodied individuals, but also negatively. ${ }^{42}$ In ancient Greek and, more systematically, ancient Roman culture, the visibly deformed and disabled were considered particularly suitable for public mockery and humiliation. ${ }^{43}$ For example, it seems to have been common for individuals who had suffered the loss of an eye to be addressed or referred to

\footnotetext{
${ }^{41}$ P.Mich. VI 425.23-4.

${ }^{42}$ See M. L. Edwards, 'Constructions of Physical Disability in the Ancient Greek World: the Community Concept', in D. Mitchell and S. Snyder (eds.) The Body and Physical Difference. Discourses of Disability (Ann Arbor MI, 1997), 35-50; M. L. Edwards, 'Deaf and Dumb in Ancient Greece', in L. Davis (ed.) The Disability Studies Reader (London, 1997), 29-51; and Rose (n. 4); see C. Laes, 'Learning from Silence: Disabled Children in Roman Antiquity', Arctos 42 (2008), 85-122 and (n. 3) on disabled children; see Graham (n. 8), 249.

${ }^{43}$ R. Garland, 'The Mockery of the Deformed and the Disabled in Graeco-Roman Culture', in S. Jäkel and A. Timonen (eds.) Laughter Down the Centuries Volume 1 (Turku, 1994), 71-84; L. Trentin, 'Deformity in the Roman Imperial Court', $G \& R 58.2$ (2011), 195-208.
} 
as 'Cyclops'. ${ }^{44}$ Robert Garland has argued that the reason for this was threefold: first, that it was a means of bolstering group cohesion at the expense of the outsider; secondly, that is was a means of expiating fear and embarrassment; and thirdly, that it was an outlet for sublimated aggression. ${ }^{45}$ That this sort of public mockery and humiliation occurred frequently is borne out by numerous ancient literary references. However, there does seem to have been a certain amount of formality involved in publically mocking and humiliating someone, both with regard to the content, and the context. It would appear that sustained mockery and humiliation regularly occurred during the symposium and the convivium, and there may even have been a religious or ritual dimension to it. ${ }^{46} \mathrm{With}$ regard to referring to an individual's disability in court, according to Cicero 'in deformity and bodily disfigurement, there is good material for making jokes, although here as elsewhere one has to know the limit'. ${ }^{47}$ What this limit was, and whether it was generally understood, is unclear, but while there may have been acceptable limits as to when and where an individual could be subjected to mockery and humiliation, no one was automatically immune from it; Spurius Carvilius, a war veteran, was so embarrassed by his disability that he refused to leave the house, despite the encouragement of his mother who was perhaps familiar with the story of Marcus Sergius Silus, and implored him to see his disability as a sign of his valour. ${ }^{48}$

The ancient literary evidence attests to the fact that disabled people were frequently subjected to various types of public mockery and humiliation in the form of

\footnotetext{
${ }^{44}$ See Ael. VH 12.43: 'The son of Philippos, Antigonos who was one-eyed, and therefore called the Cyclops'; see also Plaut. Curc. 392-400: 'I suppose that you are of the family of the Coclites; for they are one-eyed'.

${ }^{45}$ Garland (n. 43), 74.

${ }^{46}$ Hom. Il. 1.600; Hor. Sat. 1.5.50-70; Plut. Mor. 621E; SHA Heliogab. 29.3. See also Apul. Met. 2.30, where the disfigured Thelyphron is mocked as an offering to the god of laughter. Garland (n. 43), 81-3.

${ }^{47}$ Cic. De or. 2.239.

${ }^{48}$ Cic. De or. 2.249.
} 
casual ableism, insults, and jokes at their expense (the concept of political correctness being unknown in antiquity), but were they subjected to harassment in the form of physical violence? Philostratus recounts an episode in the life of Apollonius of Tyana in which a plague is ravaging Ephesus, causing the Ephesians to ask Apollonius for assistance. He identifies a blind beggar as an enemy of the gods, and instructs the Ephesians to stone him. The Ephesians are not inclined to follow his instructions, 'shocked at the idea of murdering a stranger so manifestly miserable; for he was begging and praying them to take mercy upon him' ${ }^{49}$ It is only once the blind beggar reveals himself to be a fire-eyed demon that the Ephesians proceed to stone the creature to death and set up an apotropaic statue of Herakles on the spot where it died, vanquishing the plague in the process. ${ }^{50}$

It is important to note that the examples of public mockery and humiliation found in ancient literature seem to have taken place in carefully controlled contexts, for specific, seemingly logical, reasons that ultimately sought to benefit the community. By contrast, the victimization of Gaius Gemellus Horigenes by Sotas, Julius, Julius’ wife, Zenas, and Kastor was entirely self-serving. Even the falsification of Gaius Gemellus Horigenes' liability for liturgical duties by the village elders of Karanis would not have benefitted the community, but would have been detrimental, as tasks assigned to him would have remained undone, or been reassigned, resulting in a significant amount of illwill being directed towards the village elders themselves, or perhaps towards Gaius Gemellus Horigenes for not simply bowing to the inevitable. Thus we see a fundamental

\footnotetext{
${ }^{49}$ Philostr. $V A 4.10$.

${ }^{50}$ On the scape-goating of the disabled, see W. Southwell-Wright, 'Perceptions of Infant Disability in Roman Britain', in M. Carroll and E-J. Graham (eds.) Infant Health and Death in Roman Italy and Beyond (Portsmouth RI, 2014), 111-31.
} 
difference between the information collated from ancient literary sources, and that recovered from ancient documentary sources, and this difference reiterates the importance of exploring the lived experience of actual historical disabled individuals in antiquity.

\section{Conclusion}

The family archive of Gaius Julius Niger allows us, most unusually, to reconstruct something of the lived experience of an entirely ordinary disabled individual in the Roman period. Thanks to detailed descriptions of Gaius Gemellus Horigenes' visual impairment, we know more about the precise nature of his disability than we do about the vast majority of other extent examples of disabled individuals in the ancient world, and by utilising the other literary and documentary papyri of the archive, we can not only contextualize him within his family and local community, but also assess the impact that his disability had on his quality of life.

Gaius Gemellus Horigenes' disability does not seem to have prevented him from taking his rightful place as head of a family with Antinoopolite citizenship and claiming Roman citizenship following the death of his father and uncle, although in all likelihood it made fulfilling the requirements of such positions more difficult than they would otherwise have been. He was unable to command the respect that his high status should have demanded from members of his local community, he struggled to manage and maintain the property and land that he and his sister had inherited, and he was not able to protect his mother - and presumably his sister - effectively. These difficulties offer a possible explanation as to why he does not seem to have married and had a family, but 
there is no way of knowing whether this was a choice that he made, or one that was made for him. Additionally, whatever the prevailing levels of literacy and illiteracy might have been in Egypt at the time, he was an illiterate in a literate family.

The legal petitions submitted by Gaius Gemellus Horigenes to the prefect of Egypt, the strategos, and the epistrategos, are invaluable for reconstructing the negative impact that his disability had upon his life on four separate occasions, as they indicate that he was subjected to various types of harassment that seem to have been a direct result of his disability, or at least the way that certain other members of his local community reacted and responded to his disability. The fact that he included information regarding what he perceived the perpetrators' motivations for harassing him to be, and that these motivations were directly related to his disability, indicates that this would have been considered relevant not just by Gaius Gemellus Horigenes himself, but also by those whom he was petitioning. How might the authorities have responded to Gaius Gemellus Horigenes' claims of harassment? Presumably not by condoning what his tormentors had done, for if that was likely to be the case, Gaius Gemellus Horigenes would not have included the information, or even submitted the petitions, in the first place. Perhaps with pity, if not necessarily with sympathy or empathy? It would appear that in a society in which it was perfectly acceptable to publically mock and humiliate the disabled, it was not, however, considered acceptable to continually harass and victimize them, cast magical spells upon them, steal from them, or assault them. By focusing on the lived experience of one disabled individual, and utilising that individual's family archive, it has been possible to generate a far more nuanced reconstruction of disability in antiquity than 
is often the norm. This allows us, at long last, to start to move beyond the automatic use of the emperor Claudius as the archetypal example of the disabled individual in antiquity. 